614 Meurer: Trichtergestell zum Trocknen der Niederschläge im Trichter.

Trichtergestell zum Trocknen der Niederschläge im Trichter.

(Briefliche Mittheilung.)

Von

\title{
Victor Meurer.
}

Gestatten Sie mir, dass ich Ihnen in Folgendem Mittheilung mache von einem sehr einfachen Apparat zum Trocknen der Niederschläge im Trichter, den ich mir vor einiger Zeit aus einigen Glasstäben und Glasröhren zusammengesetzt und seither zu meiner Zufriedenheit im Gebrauch habe.

Fig. 39 .

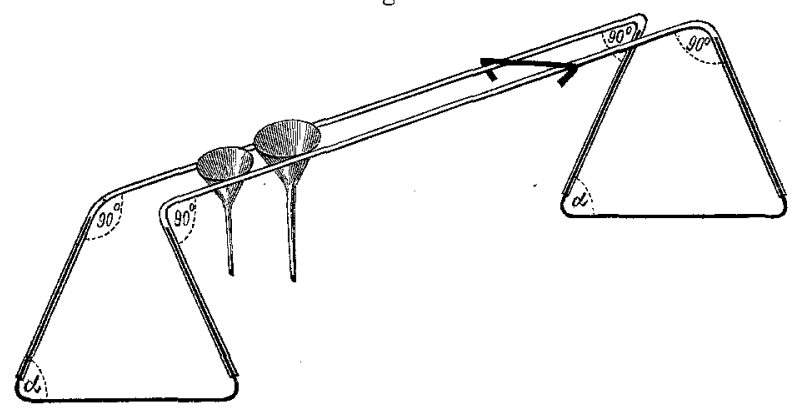

Der ganze Apparat besteht, wie aus Fig. $39 \mathrm{zu}$ ersehen ist, aus 5 Theilen, und zwar aus zwei an beiden Enden unter einem Winkel $\alpha$ gebogenen Glasstäben, ferner aus zwei unter einem. Winkel von $90^{\circ} \mathrm{ge}$ bogenen Glasröhren von solcher lichten Weite, dass sie über die Glasstäbe geschoben werden können, und schliesslich noch aus einem ebenfalls an beiden Enden umgebogenen Glasstäbchen, welches als Klammer dienen soll und aufgesetzt wird, wie aus der Fig. 38 ersichtlich ist. Die beiden horizontalen Glasröhren werden mit ihren umgebogenen Enden über die nicht parallelen Seiten der oben offenen Trapeze geschoben und der Apparat ist fertig und kann auf das Sandbad gestellt werden. Ueber die Dimensionen ist zu bemerken, dass sich der Winkel a nach der Weite richtet, welche die horizontalen Stäbe haben sollen; die Länge des ganzen Apparates hängt von dem vorhandenen Trockenraum, respective Sandbad ab.

Da in jedem Laboratorium Glasstäbe und Glasröhren verschiedener Stärke vorhanden sind, so kann der Apparat ohne grosse Kosten und Mühe hergestellt werden. Er dürfte sich besonders für Hüttenlaboratorien eignen, weil in diesen meist nur kleinere and mithin leichtere Trichter verwendet werden.

-Burbacher Hütte b./Saarbrücken, den 12. März 1887. 